\title{
Large Medial Sphenoid Wing Meningiomas: Long-Term Outcome and Correlation with Tumor Size after Microsurgical Treatment in 127 Consecutive Cases
}

\author{
Büyük Medial Sfenoid Kanat Menenjiyomları: Arka Arkaya 127 Olguda \\ Mikrocerrahi Tedavi Sonrasında Uzun Dönemli Sonuç ve Tümör \\ Büyüklüğüyle Korelasyon
}

Ding-yang LIU, Xian-rui YUAN, Qing LIU, Xin-jun JIANG, Wei-Xi JIANG, Ze-feng PENG, Xi-ping DING, Duan-wu LUO, Jian YUAN

Xiangya Hospital, Central South University, The Institute of Skull Base Surgery and Neurooncology at Hunan, Department of Neurosurgery, Changsha, Hunan 410008, China

Correspondence address: Xian-rui YUAN / E-mail: xry69@163.com

\begin{abstract}
AIM: We present the long-term outcomes as well as their correlation with tumor size in 127 consecutive patients harboring large MSWM after microsurgical treatment.

MATERIAL and METHODS: The retrospective analysis of clinical data and follow-up data of 127 microsurgical treated patients with MSWM was performed. The mean maximum diameter of tumors was $5.2 \mathrm{~cm}$ (ranged $1.5-10.0 \mathrm{~cm}$ ).

RESULTS: 104 cases (81.9\%) achieved gross total resection. There was no operative mortality. Detailed follow-up data was available in 120 cases for a mean duration of 81.6 months (12-216 months). The permanent morbidity was $14.2 \%$. The mean KPS score 1 year after surgery was 90.6 (ranged 60-100). Among 74 patients of preoperative visual acuity (VA) impairment, postoperative VA improved in 42 cases (56.8\%), unchanged in 30 (40.5\%), and deteriorated in 2 (2.7\%). MR images revealed tumor recurrence after total resection in 10 cases (10.2\%) and tumor progression after subtotal resection in 10 cases (45.5\%).

CONCLUSION: Tumor recurrence was the major risk in the long run, thus the initial surgery was extremely important and hence should be aggressive. The size of tumor affected the extent of tumor removal determining clinical outcomes including VA improvement and KPS score immediately after surgery; however, it was not correlated with long-term overall outcomes.
\end{abstract}

KEYWORDS: Medial sphenoid wing meningiomas, Tumor size, Tumor recurrence, Functional outcome

öz

AMAÇ: Büyük MSWM bulunan arka arkaya 127 olguda mikrocerrahi tedavi sonrasında uzun süreli sonuçları ve tümör büyüklüğüyle korelasyonlarını sunuyoruz.

YÖNTEM ve GEREÇLER: MSWM bulunan ve mikrocerrahi ile tedavi edilen 127 hastanın klinik verileri ve takip verilerinin retrospektif analizi yapıldı. Tümörlerin ortalama maksimum çapı $5,2 \mathrm{~cm}$ (aralık 1,5-10,0 cm) bulundu.

BULGULAR: 104 olguda $(\% 81,9)$ gros total rezeksiyon yapıldı. Operatif mortalite yoktu. Ayrıntılı takip verileri 120 olguda ortalama 81,6 ay (12-216 ay) için mevcuttu. Kalıcı morbidite \%14,2 oranında görüldü. Cerrahiden 1 yıl sonra ortalama KPS skoru 90,6 (aralık 60-100) bulundu. Preoperatif görme keskinliği bozukluğu olan 74 hasta içinde postoperatif dönemde görme keskinliği 42 hastada $(\% 56,8)$ arttı, 30'unda (\%40,5) değişmedi ve 2 'sinde $(\% 2,7)$ kötüye gitti. MR görüntüleri total rezeksiyon sonrasında 10 olguda $(\% 10,2)$ tümör reküransı ve subtotal rezeksiyon sonrasında 10 olguda $(\% 45,5)$ tümör ilerlemesi gösterdi.

SONUÇ: Uzun dönemde temel risk tümör reküransıydı ve bu nedenle ilk cerrahi çok önemlidir ve agresif olmalıdır. Tümör büyüklüğü, tümör çıkarma kapsamını etkileyerek ameliyattan hemen sonra görme keskinliği düzelmesi ve KPS skoru dahil klinik sonuçları etkiledi ancak uzun dönemli genel sonuçlarla korelasyon göstermedi.

ANAHTAR SÖZCÜKLER: Medial sfenoid kanat menenjiyomları, Tümör büyüklüğü, Tümör reküransı, İşlevsel sonuç 


\section{INTRODUCTION}

Medial sphenoid wing meningiomas (MSWM) constitute a great challenge for neurosurgeons to have complete and safe removal. They are still reported to have the worst neurological functional outcome hindering postoperative quality of life (next to petroclival meningiomas) with highest recurrence rate $(2,8,18)$, partly because of their intricate and intimate relationship with cavernous sinus (CS), arteries of anterior circulation, and optic pathways. As radiosurgery plays an increasing important role in benign tumors, there is much controversy about the indications for aggressive resection of MSWM $^{1,5,13,20}$. It was known that the more aggressive radical resection is achieved, the higher incidence of morbidity and or even mortality would be led to. However, tumor recurrence, which correlates with the extent of resection, is the greatest threat in long-term outcomes $(5,18,27)$. Therefore, it still puzzles neurosurgeons about how to balance the immediate risk of morbidity or even mortality and long-term risk of tumor recurrence.

Many neurosurgeons have observed that the clinical outcomes are even worse in larger tumors than that in smaller ones due to higher incidence of involving neural and vascular structures $(6,11,14,17,22,36)$. While, systemic studies about the correlation of tumor size with clinical characteristics and outcomes especially with long-term outcomes have not been reported in a series of large tumors.

In the present study, we evaluated the long-term outcomes of 127 consecutive cases of MSWM treated with microsurgery by the single neurosurgeon. Special attention will be paid to life quality, neurological functional outcomes, tumor recurrence. We analyzed the correlation of tumor size with clinical characteristics and outcomes.

\section{PATIENTS and METHODS}

\section{Patient population}

127 patients ( 80 female and 47 male; age ranged from 6 to $79 \mathrm{yr}$; mean age $44 \mathrm{yr}$ ) harboring MSWM were retrospectively analyzed. All patients underwent microsurgery at the Department of Neurosurgery, XiangYa Hospital of Central South University between November 1985 and November 2009 by the senior neurosurgeon (Prof. Xian-rui Yuan). All tumors were confirmed by histological examination and their origin sites were identified on radiological studies and confirmed by intraoperative inspection. However, in case giant tumor, the origin site was often difficult to determine even after intraoperative inspection, but tumors originating from tuberculum sellae, optic canal, orbital roof, planum sphenoidale, middle or lateral aspects of the sphenoid wing were excluded (15). 12 cases, that may originate from CS but the main parts were extracavernous and mainly involving MSW, were included in this study.

\section{Clinical data}

The number of patients presenting clinical symptoms and signs were shown in Table I. The average duration of clinical history was 21.5 months (ranged from 0.25 to $156 \mathrm{Mo}$ ). Ophthalmologic examinations including visual acuity (VA) and visual field (VF) were performed in all patients before and after surgery and also during follow up. Among the 74 patients with VA impairment, 65 were unilateral impairment on the side of tumor and the remaining patients were bilateral impairment. The mean duration of VA impairment was 13.8 months (ranged 1 to 72 months). Only 5 patients complained VF deficit, but when tested by computed perimetric exam, 50 patients had VF deficit. The mean KPS score was 73.8 (ranged from 40 to 100).

\section{Radiological findings}

Almost all patients underwent evaluation by $\mathrm{CT}$ scan preoperatively. Preoperative angiography was conducted in 19 cases; however preoperative embolization was not performed in any cases. Contrast-enhanced MR images were performed in 107 cases. The mean maximum diameter of the tumors calculated on MR images or CT scans was $5.2 \mathrm{~cm}$ and their distribution is shown in Table II.

\section{Surgical technique}

The Orbito-zygomatic frontotemporal approach (in 39 cases), pterional approach (in 85 cases) and subfrontal approach (in 3 cases) were performed for tumor resection. The Orbitozygomatic frontotemporal approach was used at early duration of this study (mainly between 1985 and 1999). With the increasing knowledge of the growth pattern and biological behavior of the tumors and improving surgical technical progress, the pterional approach was enough to remove most of this kind of tumors. Furthermore, it reduced

Table I: Presenting Symptoms and Signs in MSWM ( $n=127)$

\begin{tabular}{|c|c|}
\hline Symptoms/Signs & No. of cases (\%) \\
\hline headache & $65(51.2)$ \\
\hline \multicolumn{2}{|l|}{ visual disturbance } \\
\hline monocular & $65(51.2)$ \\
\hline binocular & $9(7.1)$ \\
\hline VF deficit & $50(39.4)$ \\
\hline Foster-Kennedy Syndrome & $15(11.8)$ \\
\hline seizures & $39(30.7)$ \\
\hline mental disturbance & $28(22.0)$ \\
\hline hemiparesis & $10(7.9)$ \\
\hline Motor aphasia & $5(3.9)$ \\
\hline face hypesthesia & $2(1.6)$ \\
\hline diplopia & $3(2.4)$ \\
\hline CNIII deficit & $5(3.9)$ \\
\hline CNIV deficit & $2(1.6)$ \\
\hline CNVI deficit & $3(2.4)$ \\
\hline proptosis & $6(4.7)$ \\
\hline hearing disturbance & $2(1.6)$ \\
\hline incident finding & $2(1.6)$ \\
\hline
\end{tabular}


Table II: The Distribution of Tumor Sizes of MSWM ( $n=127)$

\begin{tabular}{|c|c|}
\hline Tumor size $(\mathrm{cm})$ & No. of patients $(\%)$ \\
\hline 1.0 to 2.0 & $1(0.8)$ \\
\hline 2.1 to 3.0 & $3(2.4)$ \\
\hline 3.1 to 4.0 & $32(25.2)$ \\
\hline 4.1 to 5.0 & $27(21.2)$ \\
\hline 5.1 to 5.9 & $17(13.4)$ \\
\hline 6.0 to 6.9 & $23(18.1)$ \\
\hline 7.0 to 7.9 & $21(16.5)$ \\
\hline 8.0 to 8.9 & $2(1.6)$ \\
\hline 9.0 to 10.0 & $1(0.8)$ \\
\hline
\end{tabular}

the destruction and injury greatly. In pterional approach, we removed the outer and middle portion of sphenoid wing to the foramen ovale and superior orbital fissure, or even to anterior clinoid process (ACP) if necessary, extradurally. The ACP and optic canal were not removed routinely unless it was observed to be invaded by tumor. In cases, which the vascular or cranial nerves were encased by tumor, dissection of tumor from neurovascular structure was performed by sharp dissection cautiously avoiding violent dragging and direct coagulation as much as possible. We put great emphasis on optic nerve decompression and preservation of nutrient artery of optic nerve. After the tumor was totally removed, the dural attachment was heavily coagulated by monopolar or bipolar. If the tumor had eroded the bone, heavy coagulation with the monopolar was done after total resection of tumor. In cases of tumors involving CS, the tumor was totally removed if the adherence between tumor and ICA, $\mathrm{CN}$ was not tight. But if the tumor infiltrated the ICA and CN wildly, the extracavernous portion would be totally removed leaving the intracavernous tumor.

\section{Patients follow-up}

All patients were called for their first follow up after 3 months and then 6 months and then 1 year with clinical examinations and contrast-enhanced MR images. If there were no signs of recurrence or progression, they were called for reassessment in 1 to 2 years intervals.

\section{Statistical analysis}

All statistical analysis was performed using the SPSS 13.0 software package (Chicago, IL, USA). Chi-square test was used to determine the correlation of tumor sizes with the preand postoperative visual acuity, pre- and postoperative and follow-up KPS score, CS involvement, artery infiltration, ICA encasement, extent of resection, recurrence. All reported $p$ values were two-sided, and a value of $p<0.05$ was considered statistically significant.

\section{RESULTS}

\section{Tumor removal}

Evaluation of MR images and intraoperative inspection revealed the involvement of CS. Tumor infiltrating the lateral wall and even extending into medial compartment of CS was seen in 60 patients. In 19 cases, there was a disappearance of arachnoid dissection plane leading to adherence of tumor to ICA. The relationship with the MCA, the ACA, the optic nerve and the oculomotor nerve is shown in Table III. In our series, no ICA was sacrificed. No ICA injuries that needed reconstruction were encountered. In 10 patients the tumor extended into the optic canal, of which only one needed optic canal opening to remove the tumor, while, others can be pulled out.

The extent of removal was classified according to the criteria proposed by Simpson34 based on intraoperative inspection by the surgeon as well as contrast-enhanced MR images evaluated 3 days after surgery. Gross total removal was achieved in 104 cases (Simpson Grade I in 3 cases and grade II in 101 cases) (Figures 1A-I, 2A-G, 3A-G). Grade III was achieved in 22 cases, and grade IV in 1 case. Of the 60 cases with cavernous sinus involvement, 46 cases $(76.7 \%)$ had gross total removal. Among 67 cases without CS involvement, 58 cases $(86.6 \%)$ had total removal.

Of 14 patients $(11.0 \%)$ who had undergone surgery in other centers and later operated in our department due to tumor recurrence or progression, 10 cases $(71.4 \%)$ achieved gross total removal and 4 achieved subtotal removal. Tumors in these cases had more rampant infiltration and compact adherence to the vessels which was more difficult to remove.

\section{Pathological findings}

According to the WHO Classification ${ }^{26}, 118$ tumors were Grade I meningiomas, and 5 were Grade II, and 4 were Grade III. It's worth noting that 2 cases with Grade I at the first operation underwent malignant transformation and became Grade II or grade III at the time of second surgery.

Table III: Relationship of Tumors to Adjacent Vessels and CN ( $n=127)$

\begin{tabular}{|c|c|c|c|c|c|}
\hline \multirow{3}{*}{ Relationship } & \multicolumn{5}{|c|}{ No. of patients (\%) } \\
\hline & \multicolumn{3}{|c|}{ Cerebral arteries } & \multicolumn{2}{|c|}{ CN } \\
\hline & ICA & MCA & ACA & Optic N & Oculomotor $\mathbf{N}$ \\
\hline Dislocation & $67 / 52.8$ & $71 / 55.9$ & $48 / 37.8$ & $69 / 54.3$ & $34 / 26.8$ \\
\hline Encasement & $56 / 44.1$ & $34 / 26.8$ & $19 / 14.9$ & $15 / 11.8$ & $17 / 13.4$ \\
\hline Adherence & $19 / 14.9$ & $16 / 12.6$ & $7 / 5.5$ & $7 / 5.5$ & $8 / 6.3$ \\
\hline Stenosis & $12 / 9.4$ & $18 / 14.2$ & $3 / 2.4$ & - & - \\
\hline
\end{tabular}



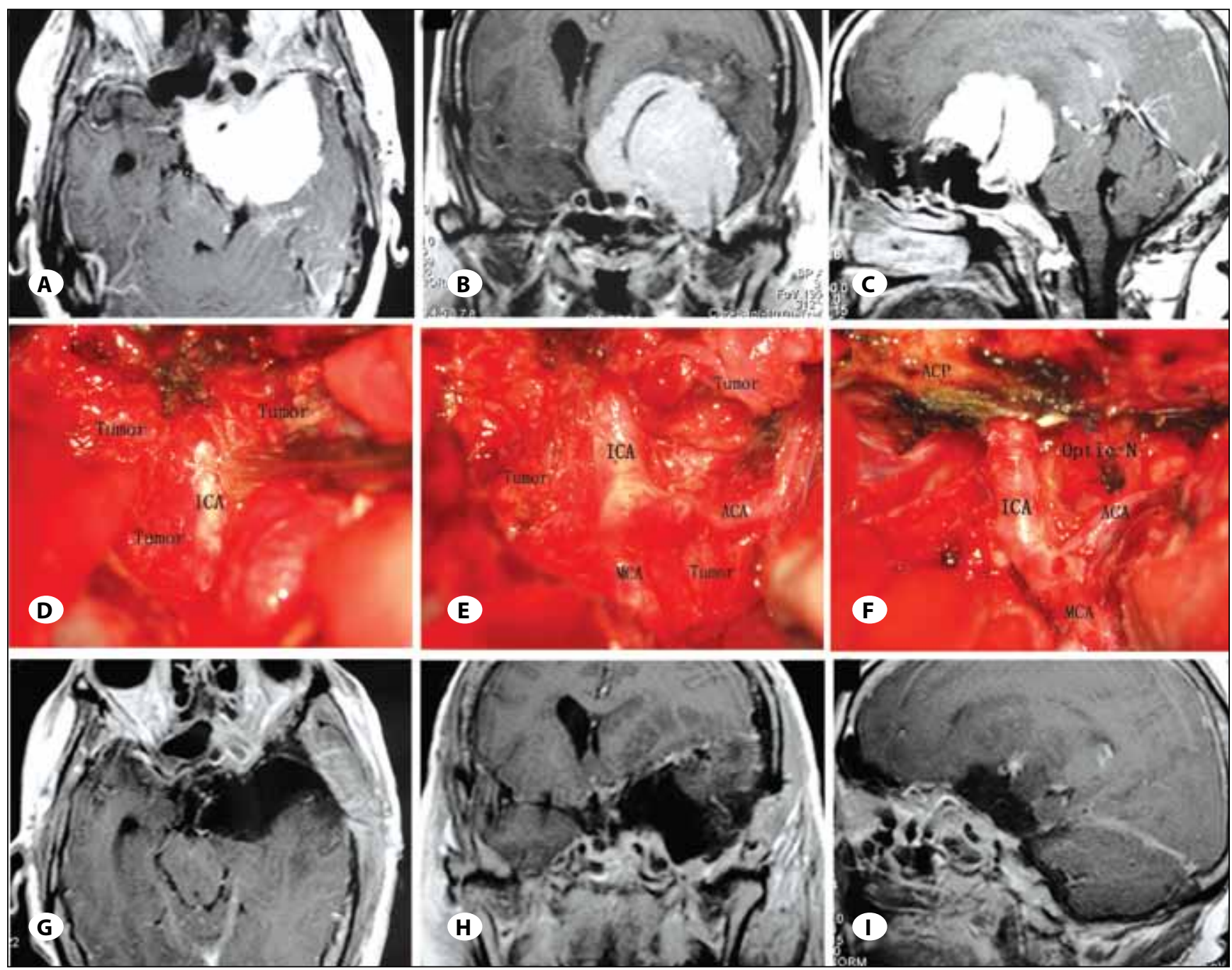

F

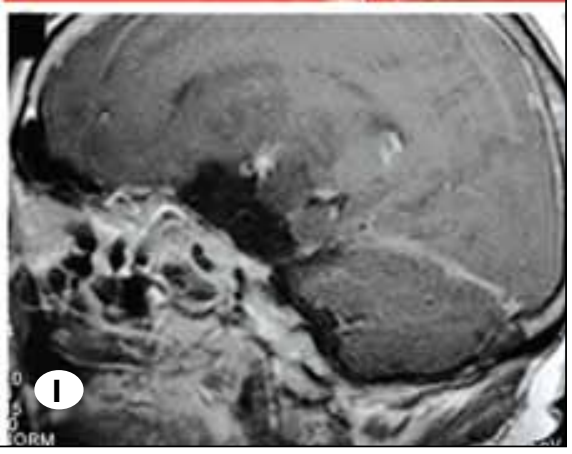

Figure 1: Contrast-enhanced T1-weighted MR images and intraoperative photographs obtained in a 55-year-old woman, who presented with hemiparalysis and bilateral visual impairment. Preoperative MR images show that the tumor encased ICA and its branches and the maximum diameter was $5.8 \mathrm{~cm}$. Intraoperative photograph (C) showing the encasement of ICA and photograph (D) (partial resection) showing the encasement of ICA and its branches by tumor and photograph (E) (total resection) showed the optic nerve, CN III and dual attachment of ACP coagulated. Postoperative MR images (G, $\mathbf{H}$ and I) confirmed total removal. VA was stable on the side of tumor and improved on the other side. Hemiparalysis was deteriorated postoperatively but improved significantly at the follow-up. The patients KPS score was 80 and observed no recurrence 5 years later.

\section{Postoperative complications and outcomes}

There was no operative mortality. 1 patient suffered from cerebrospinal fluid leakage and after the failure of expectant treatment, he needed a transnasal-endoscopic operation to repair the leakage. Epidural hematoma occurred in 2 patients, 1 recovered by expectant treatment, the other experienced increasing hemicerebral edema and had to undergo decompressive craniectomy. Meningitis occurred in 3 patients. 2 patients suffered pneumonia. 3 patients suffered from injury to the frontal branch of facial nerve.

Postoperative oculomotor nerve palsy occurred in 24 patients, among which 19 were transient and resolved later (Table IV). New postoperative oculomotor nerve palsy occurred in 19. Thirteen patients had hemiparesis after surgery including 10 with preoperative hemiparesis, and 9 improved significantly. Hypesthesia of face occurred in 6 patients and improvement occurred in 4 cases. Seizures occurred in 5 patients, among which only a case presented with seizure after surgery. As a whole, the permanent morbidity was $14.2 \%$ (17 of 120 patients).

\section{Patients follow up}

Follow-up data including clinical and imaging examinations (contrast-enhanced MR images /CT scans) was available in 120 patients (94.5\%). 7 cases lost their follow up. The mean follow-up period was 81.6 months (ranged from 12 to 216 months). In 120 patients, the mean KPS score was 90.6 (ranged from 60 to 100 ) at 1 year after surgery, which was 83.5 at 10 days after surgery (Table V). 92 patients $(76.7 \%)$ 


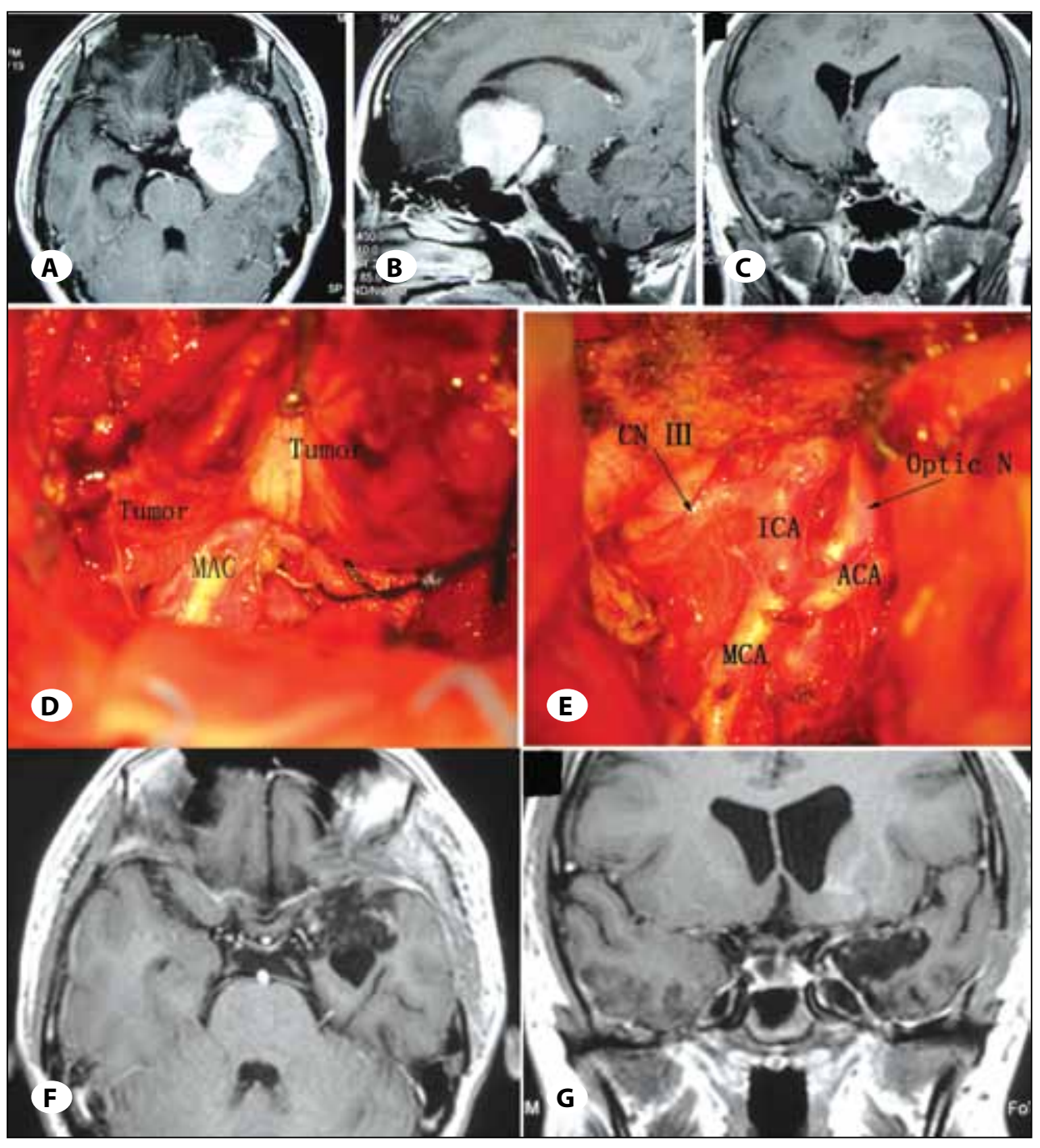

Figure 2: Contrast-enhanced T1-weighted MR images and intraoperative photographs obtained in a 28-year-old man who presented with double visual and visual acuity decreased. The maximum diameter showing on preoperative MR images (A, B) was $7.5 \mathrm{~cm}$. Intraoperative photograph (C) showing the encasement of ICA and photograph (D) (after total resection) showing the ICA and its branches and the CN III and dual attachment coagulated. Postoperative MR images confirmed total removal. The patient experienced transient oculomotor never palsy and resolved completely and have not recurred after 3 years. The visual acuity improved.

Table IV: Pre- and Postoperative and Follow-up Symptoms and Signs of MSWM

\begin{tabular}{|c|c|c|c|c|}
\hline \multirow[b]{2}{*}{ Symptoms/signs } & \multicolumn{4}{|c|}{ No. of patients } \\
\hline & $\begin{array}{l}\text { Preoperative } \\
n=127,(\%)\end{array}$ & $\begin{array}{c}\text { Postoperative } \\
n=127,(\%)\end{array}$ & $\begin{array}{c}\text { Follow-up* } \\
\text { (stable, } n=120 \text { ) }\end{array}$ & $\begin{array}{l}\text { Follow-up* } \\
\text { (resolved/improved, } n=120 \text { ) }\end{array}$ \\
\hline CN III palsy & $5(3.9)$ & $24(18.9)$ & 4 & 19 (resolved) \\
\hline Hemiparalysis & $10(7.9)$ & $13(10.2)$ & 3 & 9 (4 resolved, 5 improved) \\
\hline Motor aphasia & $5(3.9)$ & $6(4.7)$ & 2 & 4 (3 resolved, 1 improved \\
\hline Seizures & $39(30.7)$ & $5(3.9)$ & 4 & 1 (improved) \\
\hline Face hypesthesia & $2(1.6)$ & $6(6.0)$ & 2 & 4 (1 resolved, 3 improved) \\
\hline Headache & $65(51.2)$ & $18(14.2)$ & 3 & 13 (9 resolved, 4 improved) \\
\hline Mental disturbance & $28(22.1)$ & $9(7.1)$ & 3 & 6 (2 resolved, 4 improved) \\
\hline CN IV deficit & $2(1.6)$ & $4(3.1)$ & 2 & 2 (improved) \\
\hline CN VI deficit & $3(2.4)$ & $4(3.1)$ & 1 & 2 (improved) \\
\hline
\end{tabular}

*1 year after surgery, and 7 patients lost follow up. 


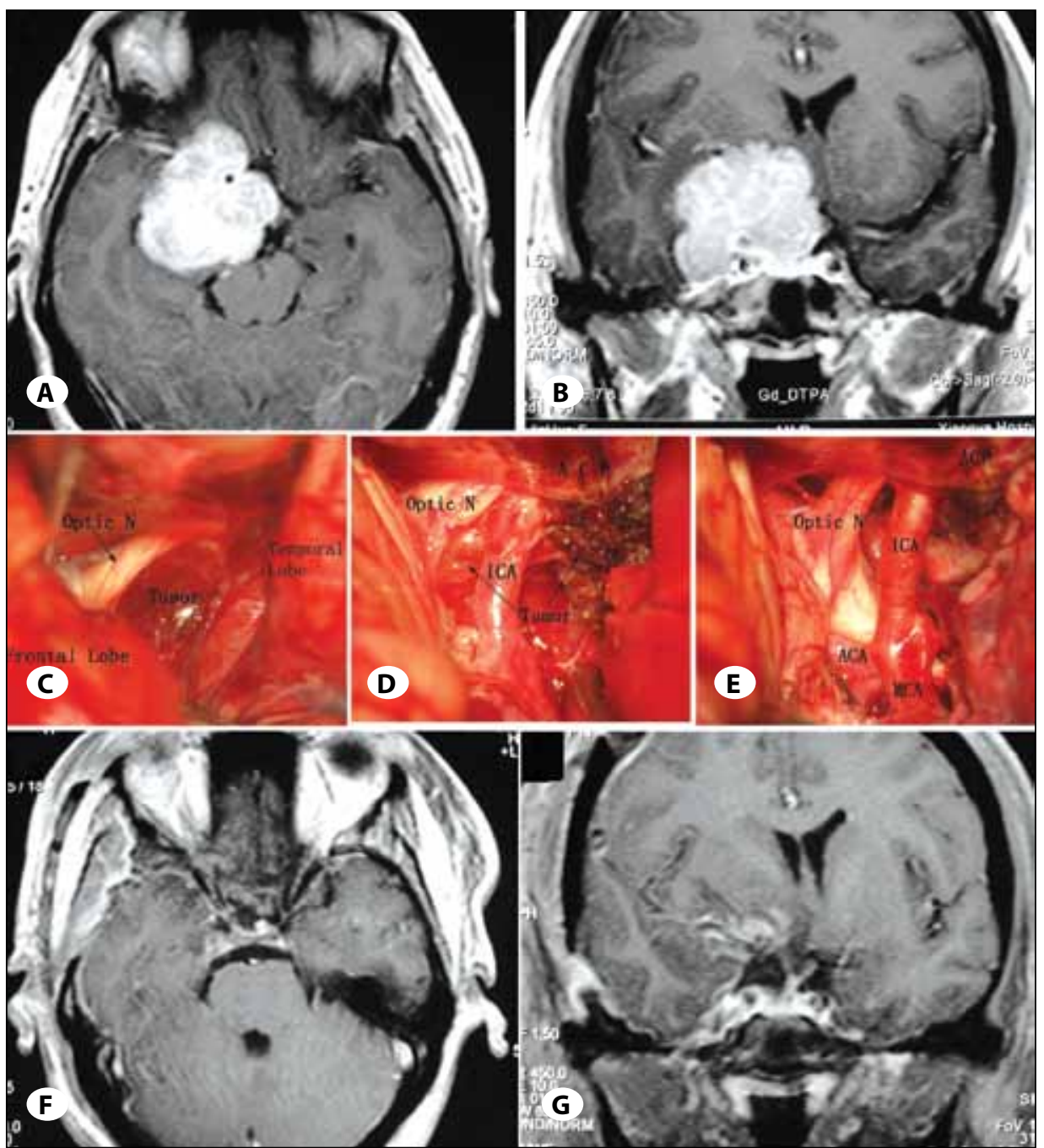

Figure 3: Contrast-enhanced T1-weighted MR images and intraoperative photographs obtained in a 44-year-old woman, who presented with binocular visual acuity decreased. Preoperative coronal MR images showing the encasement of ICA and the maximum diameter was $4.5 \mathrm{~cm}$. Photograph (C, D) showed the dislocation of optic nerve and encasement of ICA. Graph E (total removal) show the ICA and optic nerve and the dural attachment heavy coagulated. Postoperative MR images $(\mathbf{F}, \mathbf{G})$ confirmed total removal. The patient visual acuity improved to normal.
Table V: The pre-, Postoperative and Follow-up KPS Score of MSWM

\begin{tabular}{|l|c|c|c|}
\multirow{2}{*}{$\begin{array}{l}\text { KPS } \\
\text { score }\end{array}$} & $\begin{array}{c}\mid 4 \\
\text { Preoperative } \\
(\mathbf{n = 1 2 7})\end{array}$ & $\begin{array}{c}\text { 10 days after } \\
\text { surgery }(\mathbf{n = 1 2 7})\end{array}$ & $\begin{array}{c}\text { 1 year follow up } \\
(\mathbf{n}=120)\end{array}$ \\
\hline 100 & 1 & 20 & 55 \\
\hline 90 & 19 & 51 & 37 \\
\hline 80 & 45 & 34 & 13 \\
\hline 70 & 31 & 7 & 11 \\
\hline 60 & 25 & 6 & 4 \\
\hline 50 & 5 & 8 & 0 \\
\hline 40 & 1 & 1 & 0 \\
\hline 0 to 30 & 0 & 0 & 0 \\
\hline
\end{tabular}

regained full daily activity (KPS Score 90 to 100) and 24 (18.9\%) patients were able to live at home and care for most personal needs (KPS Score 70 to 80 ) and 4 patients needed permanent assistance(KPS score 60). 12 cases experienced life quality deterioration as tumor recurred or progressed.
During the follow up, 6 died of recurrence or progression of meningiomas, 2 died of unrelated diseases.

\section{Visual outcome}

We defined a change in VA as a worsening or improvement of two lines of Snellen acuity or from light-inspection to handmoving, from hand-moving to figures-countering. Among 74 patients with preoperative VA impairment, 42 improved and 30 remained unchanged and 2 worsened. Among other patients with normal VA preoperatively, 2 cases experienced VA deterioration after surgery. In the 4 patients experienced deterioration of VA, the tumor had encased and infiltrated the optic nerve. A secondary deterioration due to tumor recurrence or progression was observed in 5 patients (4.2\%) during follow up.

VF charts were available in majority of patients but few had only written description, so only gross changes in the VF were considered significant and subtle changes may be missed. Among patients with preoperative VF deficit, improvement seen in 29 cases (58\%) 4 cases who experienced postoperative deterioration of VA also had deterioration of VF. 


\section{Recurrence and progression}

Tumor recurrence that defined as tumor regrown after gross total resection was observed in 10 patients $(10.2 \%)$ based on MR images after a mean follow-up of 81.6 months. The mean interval of recurrence was 40.8 months (ranged 6-108 months).

7 patients out of 91 with benign meningiomas (WHO Grade I) were observed recurrence and the rate was 7.7\%. 1 patient out of 5 with atypical meningiomas (WHO Grade II) observed recurrence. Both of the 2 patients with malignant meningiomas (WHO Grade III) experienced recurrence. Histopathology grade shown a strong correlation with recurrence $(p<0.001)$.

Of 10 cases with recurrence, 4 underwent second surgery; 5 were treated with gamma knife surgery (GKS), and 1 denied further treatment. Among 4 patients treated with second surgery, 3 were malignant ( 2 cases undergoing the initial malignancy and 1 was benign in nature with malignant transformation) and had further deteriorated and finally died of a followed recurrence and the other case whose tumor was still benign regained fully daily activity after totally resection without recurrence. In case of 5 patients treated with GKS, the tumor did not regrow in 4 cases and reoccurred in 1 case.

Tumor progression defined as residual tumor regrown after subtotal resection. Among 22 patients with residual tumor, 9 cases underwent GKS treatment and other 13 denied further treatment. 10 cases (45.5\%) experienced tumor progression during a mean 7.2 years follow-up time. In cases of patients with GKS, the progression rate was $11 \%$ ( 1 out of 9 cases) and for those without any treatment, the rate was $69.2 \%$ (9 out of 13 cases). Eight patients experienced worsening quality of life and deterioration in neurological function significantly.

Overall, 14 patients ( 5 of recurrence tumors and 9 of residual tumors after subtotal removal) underwent GMK treatment, 12 did not regrow and the control rate was $85.7 \%$ for a mean follow up of 90.6 months. 1 patient had visual deterioration and 1 face hypesthesia on the side of tumor after GMK.

\section{Correlation of tumor size with clinical characteristics and outcomes}

The patients were divided into three subgroups according to the diameter of tumors $(\leq 4.0 \mathrm{~cm}, 4.1$ to $5.9 \mathrm{~cm}, \geq 6.0 \mathrm{~cm}$ ). In 36 patients the tumor size was $\leq 4.0 \mathrm{~cm}$. It was 4.1 to $5.9 \mathrm{~cm}$ in 44 patients and $\geq 6.0 \mathrm{~cm}$ in 47 patients. Larger tumors were associated with higher incidence of preoperative VA impairment (Table $\mathrm{Vl}, \mathrm{p}=0.047)$ ). While, there was no statistic significant difference in the postoperative visual outcome between large and small tumors $(p=0.531)$. Larger tumors correlated with lower preoperative KPS score $(p=0.032)$ and postoperative KPS score $(p=0.044)$, while, at the 1 years follow-up, there was no significant difference between large tumor and small ones $(p=0.668)$. No correlation was revealed between large tumors and small tumors with CS involvement $(p=0.753)$, while, larger tumors were more likely of ICA encasement $(p=0.042)$ and artery adventitia infiltration $(p=0.043)$. There was a statistic significance in the extent of resection distribution between large and medium and small tumors $(p=0.032)$. Tumor recurrence was not significantly corrected with the tumor size $(p=0.209)$.

\section{DISCUSSION}

\section{Tumor removal}

Medial sphenoid wing meningiomas are still challenging lesions to remove totally and safely. The overall outcomes reported recently for MSWM were shown in Table VII. The treatment of meningiomas involving CS has been continuously debated and remains controversial. Some

Table VI: Correlation of Tumor Sizes with the Characteristics and Outcomes of MSWM

\begin{tabular}{|c|c|c|c|c|}
\hline \multirow{2}{*}{ variable } & \multicolumn{3}{|c|}{ Tumor size $(\mathrm{cm})$} & \multirow{2}{*}{$\begin{array}{c}P \\
\text { value }\end{array}$} \\
\hline & $\leq 4$ & 4.1 to 5.9 & $\geq 6$ & \\
\hline Preoperative VA & & & & \multirow{3}{*}{0.047} \\
\hline impairment & 15 & 27 & 32 & \\
\hline normal & 21 & 17 & 15 & \\
\hline \multicolumn{4}{|l|}{ Postoperative VA } & \multirow{3}{*}{0.531} \\
\hline Improvement & 10 & 16 & 16 & \\
\hline Stable/deterioration & 5 & $9 / 2$ & 16 & \\
\hline \multicolumn{4}{|l|}{ Preoperative KPS score } & \multirow{3}{*}{0.032} \\
\hline$\geq 90$ & 10 & 7 & 3 & \\
\hline$<90$ & 26 & 37 & 44 & \\
\hline \multicolumn{4}{|l|}{ Postoperative KPS score } & \multirow{3}{*}{0.044} \\
\hline$\geq 90$ & 25 & 26 & 20 & \\
\hline$<90$ & 11 & 18 & 27 & \\
\hline \multicolumn{4}{|l|}{ Follow-up KPS score } & \multirow{3}{*}{0.668} \\
\hline$\geq 90$ & 28 & 29 & 35 & \\
\hline$<90$ & 6 & 10 & 12 & \\
\hline \multicolumn{4}{|l|}{ CS involvement } & \multirow{3}{*}{0.753} \\
\hline Yes & 17 & 19 & 24 & \\
\hline No & 19 & 25 & 23 & \\
\hline \multicolumn{4}{|l|}{ ICA encasement } & \multirow{3}{*}{0.042} \\
\hline Yes & 10 & 20 & 26 & \\
\hline No & 26 & 24 & 21 & \\
\hline \multicolumn{4}{|l|}{ adventitia infiltration } & \multirow{3}{*}{0.043} \\
\hline yes & 4 & 9 & 16 & \\
\hline No & 32 & 35 & 31 & \\
\hline \multicolumn{4}{|l|}{ Extent of resection } & \multirow{3}{*}{0.032} \\
\hline Gross total & 32 & 39 & 33 & \\
\hline Subtotal & 4 & 5 & 14 & \\
\hline \multicolumn{4}{|l|}{ Recurrence } & \multirow{3}{*}{0.209} \\
\hline Yes & 4 & 1 & 5 & \\
\hline No & 25 & 34 & 30 & \\
\hline
\end{tabular}


Table VII: Review of Microsurgical Series Reporting on MSWM

\begin{tabular}{|c|c|c|c|c|c|c|c|c|}
\hline Authors/year & $\begin{array}{c}\text { No. of } \\
\text { tumors } \\
\text { (recurren- } \\
\text { ces) }\end{array}$ & $\begin{array}{l}\text { Tumors } \\
\text { size } \\
(\mathrm{cm})\end{array}$ & $\begin{array}{c}\% \text { CS } \\
\text { involvement }\end{array}$ & $\begin{array}{c}\text { \%Total } \\
\text { resection }\end{array}$ & $\begin{array}{c}\text { VA } \\
\text { impairment } \\
\text { (\%improved) }\end{array}$ & $\begin{array}{c}\text { Morbidity\#/ } \\
\text { mortality }\end{array}$ & $\begin{array}{l}\text { Mean } \\
\text { follow-up } \\
\text { (mo) }\end{array}$ & $\begin{array}{l}\text { \%Recurrence } \\
\text { /progression }\end{array}$ \\
\hline Al-Mefty, $1990^{2}$ & $24(4)$ & na & 38 & 83 & $21(25)$ & $17 / 8$ & 57 & $0 / 50$ \\
\hline Puzzilli, $1999^{25}$ & 33 & na & 39 & 55 & 15 (na) & $24 / 15$ & 53.7 & $0 / 42$ \\
\hline Goel, $2000^{11}$ & 60 & $85 \%>3$ & 0 & 70 & $55(25.5)$ & $11.7 / 5$ & NA & NA \\
\hline Lee, $2001^{14}$ & 15 & $53 \%>3$ & 13 & 86.7 & $12(75)$ & $6.7 / 0$ & 37.2 & 0 \\
\hline Tomasella, $2003^{38}$ & 13 & $>5$ & 7.7 & 77 & 3 (na) & $7.7 / 15.4$ & 48.3 & $0 / 100$ \\
\hline Tobias, $2003^{37}$ & $26(2)$ & na & 23 & 77 & 14 (76.9) & $0 / 0$ & 42.3 & $0 / 0$ \\
\hline Abdel-Aziz, 2004¹ & 38 & na & 100 & 58 & $15(\mathrm{na})$ & $16 / 0$ & 96 & $9 / 12.5$ \\
\hline Nakamura, $2006^{20}$ & $108(28)$ & na & 64 & 43 & $68(32.4)$ & $\mathrm{NA} / 0$ & 79 & $23^{*}$ \\
\hline Behari, $2008^{6}$ & 20 & 6.12 & 90 & 45 & $20(15)$ & $\mathrm{Na} / 5$ & na & na \\
\hline Pamir, $2008^{22}$ & $43(4)$ & 3.6 & na & 90.7 & $26(84.6)$ & $\mathrm{Na} / 0$ & 39 & $11^{*}$ \\
\hline Russell, $2008^{28}$ & $35(6)$ & 4.6 & 31.4 & 68.6 & $30(73.3)$ & $18 / 0$ & 153 & $0 / 27.3$ \\
\hline Bassiouni, 20095 & $106(1)$ & na & 29 & 58 & $52(40.4)$ & $17 / 1.9$ & 83 & $16.1 / 39$ \\
\hline Present series & $127(14)$ & 5.2 & 47.2 & 81.9 & $74(56.8)$ & $14.2 / 0$ & 81.6 & $10.2 / 42$ \\
\hline
\end{tabular}

*The authors did not differentiate between recurrence and progression.

\# Only permanent morbidity was considered. Mortality was referred to operative mortality.

$\mathbf{N a}=$ not available.

authors $(6,9,30-32)$ proposed a radical and aggressive resection whereas, some authors $(5,13,20,21,23,28,35)$ proposed a conservative strategy with or without following radiosurgery. In our series, total removal was achieved in 104 cases (81.2\%), and of 60 cases with CS involvement, 47 were achieved total removal. CS involvement limits the extent of tumor removal, but if patients have either severe preoperative $\mathrm{CN}$ deficit or minimal intraoperative adherences to the $\mathrm{CN}$ or ICA, we think aggressive surgery should be justified and must be performed to low the risk of new recurrence. However, if the neurological deficit is not evident and the tumor encasement and infiltration to the CN or ICA is present with tight adherence, we should take conservative resection to improve functional outcome.

Cerebral ischemia that results from direct injury or secondary spasm of arteries especially important perforating arteries may cause severe neurological defect. Balloon occlusion test (BOT), a safe and effective method to test the patient's tolerance to occlusion of ICA, was useful and gave important information to help the surgeon making the decision in cases that ICA was encased by tumor. However, it was not performed before operation in any patients. In our experience, if the tumor was neither too hard nor seriously infiltrated ICA, it was possible to separate the tumor from ICA safely after ICA was identified. The philosophy of conservative resection was also need to be considered if the total removal was in cost of ICA sacrifices. In our series, no ICA was sacrificed. No ICA injuries that needed reconstruction were encountered. In 9 patients, the ICA and its branches were encased and directly infiltrated by tumor and adherence was very tight; total removal was therefore impossible without injury and hence small pieces of the tumor had to be left in situ.

Simpson (34) classified the extent of tumor removal into 5 grades and put great emphasis on dural and bony attachments. In the majority of cases in our series, the dural and bony attachments were heavily coagulated after tumor removal by unipolar or bipolar coagulation instead of resection. Some authors $(7,8)$ stated that hyperostosis must be considered of bone invasion by tumors and the bony attachment should be removed. In small tumors it was usually accessible, while, in large or giant tumors, the tumor infiltrate wildly and more difficulty may be encountered to remove all of the dural and bony attachments radically which may increase the risk of injury of neural structure and exposure-induced complications. Nakanuma et al. (20) found that there was no statistically difference of recurrence rate between group with bone removal and group without removal. We considered that heavy coagulation of dural can maybe kill most of even all of the tumor cells and can replace radically resection if no signs of erosion of bone inspected at the surgery and images. At a mean follow-up of 81.6 months, the tumor recurrence occurred in $10.2 \%$ patients. However, given the small number of cases and as no comparative study was performed, the views must taken with caution and more investigations including longer follow up and a comparative study of larger series should be performed to support this hypothesis.

\section{Neurological functional outcomes}

It was reported that complications after surgery were related with the extent of tumor resection. Al-Mefty(2-4) reported 
total removal achieved in 20 cases with morbidity rate of $25 \%$ and mortality rate $42.9 \%$ in a series of 24 cases. In our series, the permanent morbidity was $14.2 \%$ and mostly resulted from neuro-ophthalmological deficit and hemiparesis. Ischemia that results from direct injury or vasospasm of ICA and its branches will lead neurological deficit. Careful manipulation and great caution should be taken to separate the tumor from involved vessels. No direct injury of MCA and ICA occurred in our series, 9 cases of 13 who experienced hemiparalysis after surgery improved significantly at the follow up.

Neurological outcome on long-term follow-up was not usually considered in previous report. Abdel-Aziz et al. (1) reported excellent results in their survey of 38 patients, with a persistent morbidity in $16 \%$ and a KPS score $>90$ in $89 \%$ of their cases 1 year after surgery. Bassiouni et al. (5) reported a deterioration in neurological condition in $14 \%$ of 96 cases due to tumor progression for a mean period of 6.9 years follow-up. In our series, 12 (10\%) experienced a second life quality deterioration due to tumor recurrence or progression including 6 died of their tumors.

\section{Visual outcome}

The past views regarding postoperative visual recovery were quite pessimistic. Although the visual outcome had seen some progress in recent years, the overall outcomes remains unsatisfactory $(5,6,11,19)$. In our series, 74 patients presented preoperative VA impairment, and postoperatively, the VA improved in 43 cases (56\%), unchanged in 29 (39.2\%), and deteriorated in 2 (2.7\%). Bassiouni et al. (5) reported of 106 cases harboring ACP meningiomas, among which 57 presented a VA disturbance preoperatively. VA improved in 21 cases (40.4\%). Lee et al.(14-16) reported a fair results using a cranial base technique consisting of extradural anterior clinoidectomy coupled with optic canal and optic sheath opening. 8 out of 12 were significantly improved. They also analyzed 52 cases of clinoid meningiomas, 19 (36\%) had optic canal involvement, and considered it was a rationale for aggressive skull base approach (29). In our series, the tumor extending into optic nerve canal was encountered in 10 cases, and the tumor can be pulled out in 9 and only in 1 case the tumor infiltrated the optic canal or optic nerve and needed optic canal opening. We consider aggressive skull base approach of clinoidectomy with optic canal unroofing routinely is unnecessary unless the tumor originates from optic canal or infiltrates in optic canal, in which case the tumor can not be pulled out.

\section{Recurrence and progression}

Many factors impacted on tumor recurrence of meningiomas reported previously, including tumor sizes, involvement of CS, pathology grade, extent of resection, and peritumoral edema. In our series, 46 patients with CS involvement reached total resection, however 6 (13.3\%) experienced recurrence. The recurrence rate of those without CS involvement was $7.5 \%$. It was well documented that tumor recurrence was strongly related to the pathological grade of the meningioma. The pathological WHO Grade was significantly impacted on tumor recurrence in our series. In atypical and malignant meningiomas, recurrence is almost always inevitable, therefore, we advocated that WHO Grade II and III was an indicator of adjuvant radiotherapy after tumor removal.

The surgical treatment for recurrence tumor was even more difficult than that in the first time operation (20). In our series, 14 patients had undergone surgery in other center and experienced recurrence, the rate of total removal (71.4\%) was lower than the patients performed the first operation (83.2\%). Among the 10 patients who experienced recurrence, 4 underwent a second surgery and 3 died of their tumor which belongs to WHO grade II or III. Recurrence tumors had a higher incidence of directly encroaching the adventitia of ICA and its branches and the tumor rampant infiltrated adjacent structure; furthermore, they may experience pathological malignant transformation. Therefore, the first operation is extremely important and should be aggressive and vigilant. At the same time we should be careful to treat tumor attachments to minimize recurrence. When tumor residual is inevitable, the radiosurgery treatment should be performed to control the regrowth of tumor, especially in those whose close image follow-up is not possible.

\section{Tumor size}

It was reported that difficulty of surgery, extent of tumor removal, associated surgical risks, and patients outcomes are related to the tumor size in meningiomas of suprasellar and parasellar region $(6,11,14,17,22,36)$. Goel et al. (11) proposed a different system for grading ACP meningiomas, in which tumor size was included as an impact factors. They indicated a high risk of surgical failure for those larger than $3 \mathrm{~cm}$ (35.3\% for this group vs. 0\% for smaller tumors). Pamir et al. (22) stated that tumor size should be incorporated into classification scheme for determining clinical and surgical risk. They found that tumor size larger than $2 \mathrm{~cm}$ may be more unfavourable regarding the extent of resection and outcome than those smaller than $2 \mathrm{~cm}$, due to distal adherence to neural structure and vascular. In our series, the tumor size had significant effect on preoperative VA impairment, while, did not significant related to postoperative VA outcome. The tumor impact on preoperative VA by direct and indirect compression or devascularization, therefore, large tumor had more mass effect that led to visual dysfunctions. To our knowledge, the postoperative visual outcome had some more impact factors. Our experience was that the relationship of tumor and optic nerve play the key role in postoperative visual outcomes, such as optic nerve involvement and optic nerve encasement. In all of the 4 patients who experienced VA deterioration postoperatively, the optic nerve was encased by tumor and its nutritional artery was destructed severely. Careful manipulation was also important, while, the tumor size had a minor weight in visual postoperative outcome.

Preoperative and postoperative life quality was associated with tumor size in our series. At the follow-up of 1 year after surgery, no statistic difference of life quality was 
found between large tumor and small tumors. Life quality depended on neurological function. Postoperative life quality immediately after surgery was associated with preoperative status. In our series, the extent of resection was correlated with tumor size. Large tumors were more likely experiencing ICA encasement and artery infiltration, which may significantly impact on tumor removal. The tumor size did not correlate with recurrence significantly, partly because in all of the cases we treated the tumor attachment radically and recurrence was greatly impacted by pathological grade.

\section{Radiosurgery}

Radiosurgery has proved to be an effective adjuvant therapy in controlling growth of meningiomas and plays a important role in meningiomas involving CS. Actual tumorgrowth control rate after GMK of CS meningiomas ranged from $91 \%$ to $96.5 \%$ at 5 years and $82 \%$ to $94 \%$ at 10 years $(10,12,13,16,23,24,35)$. In our series, $85.7 \%$ patients (12 out of 14 patients) after GMK treatment did not regrow for a mean follow up of 90.6 months and 2 patients had related acceptable complications, including 1 patient had visual deterioration and 1 face hypesthesia on the side of tumor after GMK. Radiosurgery shows acceptable results of long-term tumor control and related complications for small recurrence or residual tumors. The treatment should cover the entire tumor volume with an adequately high radiation dosage to achieve a high tumor control rate (33). Therefore, if a small piece of tumor has to be left in situ, we should minify the residual tumor volume as long as possible. Careful monitoring of recurrence or progression is also necessary.

\section{CONCLUSIONS}

The surgical treatment of medial sphenoid wing meningiomas still remains a challenge for neurosurgeons. Simpson Grade II resection had acceptable outcomes associated with minimal recurrence. However, in our experience, the clinoidectomy with optic canal opening routinely was not necessary unless the tumors infiltrated the canal. Tumor recurrence and progression was the major risk in the long run, and the first operation was extremely important and vigilant. At the same time we should be careful to treat the tumor attachments so as to minimize the risk of recurrence. Radiosurgery served as a promising adjuvant therapy for small residual or recurrence tumors. Large tumors do have poorer clinical outcome including visual improvement and KPS score immediately after surgery and encounter more difficulty to removal totally, but, in the long run, the tumor size was not correlated with long-term overall outcomes by our treatment strategy.

\section{ACKNOWLEDGEMENT}

We thank all the patients who trusted us and all the physicians and staff who help this study.

\section{APPENDICES}

Abbreviations used in this paper: $\mathbf{M S W M}=$ medial sphenoid wing meningiomas; $\mathbf{A C P}=$ anterior clinoidal process; $\mathbf{C N}=$ cranial never; $\mathbf{C S}=$ cavernous sinus; $\mathbf{G K S}=$ Gamma knife surgery; ICA=internal carotid artery; $\mathbf{A C A}=$ anterior cerebral artery; $\mathbf{M C A}=$ middle cerebral artery; $\mathbf{K P S}=$ Karnofsky Performance Scale. $\mathbf{V A}=$ visual acuity; $\mathbf{V F}=$ visual field.

\section{REFERENCES}

1. Abdel-Aziz KM, Froelich SC, Dagnew E, Jean W, Breneman JC, Zuccarello M, van Loveren HR, Tew JM Jr: Large sphenoid wing meningiomas involving the cavernous sinus: Conservative surgical strategies for better functional outcomes. Neurosurgery 54:1375-1383, discussion 13831374, 2004

2. Al-Mefty O: Clinoidal meningiomas. J Neurosurg 73:840-849, 1990

3. al-Mefty O, Ayoubi S: Clinoidal meningiomas. Acta Neurochir Suppl (Wien) 53:92-97, 1991

4. Al-Mefty O, Smith RR: Surgery of tumors invading the cavernous sinus. Surg Neurol 30:370-381, 1988

5. Bassiouni H, Asgari S, Sandalcioglu IE, Seifert V, Stolke D, Marquardt G: Anterior clinoidal meningiomas: Functional outcome after microsurgical resection in a consecutive series of 106 patients. Clinical article. J Neurosurg 111:1078-1090, 2009

6. Behari S, Giri PJ, Shukla D, Jain VK, Banerji D: Surgical strategies for giant medial sphenoid wing meningiomas: A new scoring system for predicting extent of resection. Acta Neurochir (Wien) 150:865-877, discussion 877, 2008

7. Bikmaz K, Mrak R, Al-Mefty O: Management of bone-invasive, hyperostotic sphenoid wing meningiomas. J Neurosurg 107:905-912, 2007

8. Bonnal J, Thibaut A, Brotchi J, Born J: Invading meningiomas of the sphenoid ridge. J Neurosurg 53:587-599, 1980

9. DeMonte F, Smith HK, al-Mefty O: Outcome of aggressive removal of cavernous sinus meningiomas. J Neurosurg 81:245-251, 1994

10. Dufour H, Muracciole X, Metellus P, Regis J, Chinot O, Grisoli F: Long-term tumor control and functional outcome in patients with cavernous sinus meningiomas treated by radiotherapy with or without previous surgery: Is there an alternative to aggressive tumor removal? Neurosurgery 48:285-294, discussion 294-286, 2001

11. Goel A, Gupta S, Desai K: New grading system to predict resectability of anterior clinoid meningiomas. Neurol Med Chir (Tokyo) 40:610-616; discussion 616-617, 2000

12. Iwai Y, Yamanaka K, Ishiguro T: Gamma knife radiosurgery for the treatment of cavernous sinus meningiomas. Neurosurgery 52:517-524, discussion 523-514, 2003

13. Klink DF, Sampath P, Miller NR, Brem H, Long DM: Long-term visual outcome after nonradical microsurgery patients with parasellar and cavernous sinus meningiomas. Neurosurgery 47:24-31, discussion 31-22, 2000

14. Lee JH, Jeun SS, Evans J, Kosmorsky G: Surgical management of clinoidal meningiomas. Neurosurgery 48:1012-1019, discussion 1019-1021, 2001

15. Lee $\mathrm{JH}$, Sade B, Park BJ: A surgical technique for the removal of clinoidal meningiomas. Neurosurgery 59:ONS108-114, discussion ONS108-114, 2006 
16. Lee JY, Niranjan A, Mclnerney J, Kondziolka D, Flickinger JC, Lunsford LD: Stereotactic radiosurgery providing long-term tumor control of cavernous sinus meningiomas. J Neurosurg 97:65-72, 2002

17. Margalit NS, Lesser JB, Moche J, Sen C: Meningiomas involving the optic nerve: technical aspects and outcomes for a series of 50 patients. Neurosurgery 53:523-532, discussion 532-523, 2003

18. Mathiesen T, Lindquist C, Kihlstrom L, Karlsson B: Recurrence of cranial base meningiomas. Neurosurgery 39:2-7, discussion 8-9, 1996

19. Mehrazin M, Mirfalah R: Early post operative visual outcome in microsurgically treated suprasellar meningiomas predict long-term visual outcome. Turk Neurosurg 18:380-386, 2008

20. Nakamura M, Roser F, Jacobs C, Vorkapic P, Samii M: Medial sphenoid wing meningiomas: Clinical outcome and recurrence rate. Neurosurgery 58:626-639, discussion 626639,2006

21. O'Sullivan MG, van Loveren HR, Tew JM, Jr: The surgical resectability of meningiomas of the cavernous sinus. Neurosurgery 40:238-244, discussion 245-237, 1997

22. Pamir MN, Belirgen M, Ozduman K, Kilic T, Ozek M: Anterior clinoidal meningiomas: Analysis of 43 consecutive surgically treated cases. Acta Neurochir (Wien) 150:625-635, discussion 635-626, 2008

23. Pamir MN, Kilic T, Bayrakli F, Peker S: Changing treatment strategy of cavernous sinus meningiomas: Experience of a single institution. Surg Neurol 64 Suppl 2:S58-66, 2005

24. Peele KA, Kennerdell JS, Maroon JC, Kalnicki S, Kazim M, Gardner T, Malton M, Goodglick T, Rosen C: The role of postoperative irradiation in the management of sphenoid wing meningiomas. A preliminary report. Ophthalmology 103:1761-1766, discussion 1766-1767, 1996

25. Puzzilli F, Ruggeri A, Mastronardi L, Agrillo A, Ferrante L: Anterior clinoidal meningiomas: Report of a series of 33 patients operated on through the pterional approach. Neuro Oncol 1:188-195, 1999

26. Radner H, Blumcke I, Reifenberger G, Wiestler OD: The new WHO classification of tumors of the nervous system 2000. Pathology and genetics. Pathologe 23:260-283, 2002
27. Risi $\mathrm{P}$, Uske $\mathrm{A}$, de Tribolet $\mathrm{N}$ : Meningiomas involving the anterior clinoid process. Br J Neurosurg 8:295-305, 1994

28. Russell SM, Benjamin V: Medial sphenoid ridge meningiomas: classification, microsurgical anatomy, operative nuances, and long-term surgical outcome in 35 consecutive patients. Neurosurgery 62:38-50, discussion 50, 2008

29. Sade B, Lee $\mathrm{JH}$ : High incidence of optic canal involvement in clinoidal meningiomas: Rationale for aggressive skull base approach. Acta Neurochir (Wien) 150:1127-1132, discussion 1132,2008

30. Sekhar LN, Moller AR: Operative management of tumors involving the cavernous sinus. J Neurosurg 64:879-889, 1986

31. Sekhar LN, Patel S, Cusimano M, Wright DC, Sen CN, Bank WO: Surgical treatment of meningiomas involving the cavernous sinus: Evolving ideas based on a ten year experience. Acta Neurochir Suppl 65:58-62, 1996

32. Sekhar LN, Sen CN, Jho HD: Saphenous vein graft bypass of the cavernous internal carotid artery. J Neurosurg 72:35-41, 1990

33. Shin M, Kurita $H$, Sasaki T, Kawamoto $S$, Tago M, Kawahara $N$, Morita A, Ueki K, Kirino T: Analysis of treatment outcome after stereotactic radiosurgery for cavernous sinus meningiomas. J Neurosurg 95:435-439, 2001

34. Simpson D: The recurrence of intracranial meningiomas after surgical treatment. J Neurol Neurosurg Psychiatry 20:22-39, 1957

35. Sindou M, Wydh E, Jouanneau E, Nebbal M, Lieutaud T: Longterm follow-up of meningiomas of the cavernous sinus after surgical treatment alone. J Neurosurg 107:937-944, 2007

36. Symon L, Rosenstein J: Surgical management of suprasellar meningioma. Part 1: The influence of tumor size, duration of symptoms, and microsurgery on surgical outcome in 101 consecutive cases. J Neurosurg 61:633-641, 1984

37. Tobias S, Kim CH, Kosmorsky G, Lee JH: Management of surgical clinoidal meningiomas. Neurosurg Focus 14:e5, 2003

38. Tomasello F, de Divitiis O, Angileri FF, Salpietro FM, d'Avella D: Large sphenocavernous meningiomas: Is there still a role for the intradural approach via the pterional-transsylvian route? Acta Neurochir (Wien) 145:273-282, discussion 282, 2003 